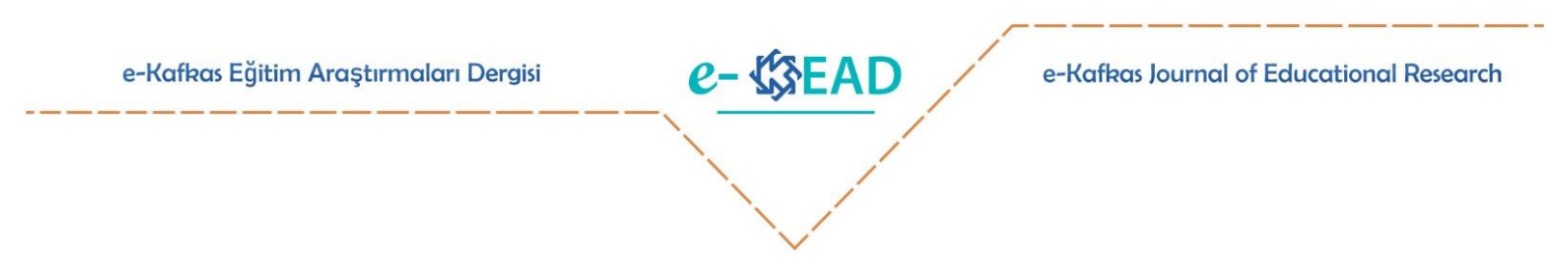

\title{
Türkiye'de Okul Öncesi Dönem Çocuklarının Psikomotor Gelişimlerini Destekleyen Eğitim Uygulamalarının İncelenmesi: Bir Meta-Analiz Çalışması ${ }^{1}$
}

\author{
Osman Basit (1) $ه$ Ümit Deniz (D)
}

\begin{abstract}
Atıf: Basit, O. ve Deniz, Ü. (2020). Türkiye'de okul öncesi dönem çocuklarının psikomotor gelişimini destekleyen eğitim uygulamalarının incelenmesi: Bir meta-analiz çalışması. e- Kafkas Eğitim Araştırmaları Dergisi, 7, 100-118. doi: 10.30900/kafkasegt.743149
\end{abstract}

Araştırma Makalesi

Geliş Tarihi:27.05.2020
Kabul Tarihi: 10.07 .2020

\section{$\ddot{O} z$}

Bütün bilim dallarında olduğu gibi okul öncesi eğitim alanında da her geçen gün bilimsel yayınların sayısı artmaktadır. Fakat hızla büyüyen bilimsel bilgi yı̆̆ınının sentezlenmesi ve düzenli hale getirilmesi gerekmektedir. Farklı yöntem, örneklem ve zamanlarda, benzer amaçlar ile gerçekleştirilmiş bireysel çalışmaların sentezlenmesi bütünün görülmesi açısından önem arz etmektedir. Bu araştırmanın amacı, Türkiye'de 1998-2020 yılları arasında yayınlanan lisansüstü tezler kapsamında, okul öncesi dönem çocuklarına uygulanan eğitimsel müdahale programlarının çocukların psikomotor gelişimlerine etkisini belirlemektir. Araştırmanın verileri Ulusal Tez Merkezi üzerinden yapılan taramalar sonucunda elde edilmiştir. 1080 tez içerisinden araştırmaya dâhil edilme kriterlerini karşılayan 28 tez araştırma kapsamında ele alınmıştır. 19982020 yılları arasında yayınlanmış, okul öncesi dönem çocuklarına yönelik uygulanan eğitimsel müdahaleleri içeren, deneysel desende tasarlanmış ve uygun verilere sahip 28 tezden, toplam 1575 okul öncesi dönem çocuğunun oluşturduğu bir örnekleme ulaşılmıştır. Meta-analiz ile ilgili yapılması gereken bütün istatistiksel işlemler Comprehensive Meta-Analysis V3.0 (CMA) yazılımı deneme kopyasında gerçekleştirilmiştir. Araştırma sonucunda okul öncesi dönem çocukların psikomotor gelişimlerini destekleyen lisansüstü çalışmaların sayısının son yıllarda arttığı sonucuna varılmıştır. Meta-analiz kapsamında incelenen 28 lisansüstü tezdeki eğitimsel müdahalelerin etki büyüklükleri birleştirildiğinde uygulanan programların okul öncesi dönem çocuklarının psikomotor gelişim alanlarını orta büyüklükte etkilediği tespit edilmiştir. Bu sonuçlara bağlı olarak, okul öncesi dönem çocuklarının diğer gelişim alanlarını ilgilendiren çalışmaların yapılması önerilmektedir.

Anahtar Sözcükler: Psikomotor, okul öncesi, meta-analiz

\section{Abstract}

As in all branches of science, the number of scientific publications is increasing day by day in the field of preschool education. However, the rapidly growing scientific information stack needs to be synthesized and organized. The synthesis of individual studies carried out for similar purposes at different methods, samples, and times is essential in terms of seeing the whole. This study aims to determine the scope of pre-school graduate theses published between the years of 1998-2020 in Turkey early childhood intervention program applied to the educational effects on children's psychomotor development. The data of the research was obtained as a result of the screenings made through the National Thesis Center. Among 1080 theses, 28 theses that meet the criteria for inclusion in the research are discussed. A sample of 1575 pre-school children was reached from 28 theses published between 1998-2020, containing educational interventions for pre-school children, designed in experimental design and with appropriate data. All the statistical procedures required for meta-analysis were performed in the Comprehensive Meta-Analysis V3.0 (CMA) software trial copy. As a result of the research, it is concluded that the number of postgraduate studies supporting the psychomotor development of pre-school children has increased in recent years. When the effect sizes of the educational interventions in 28 postgraduate theses examined within the scope of the meta-analysis were combined, it was found that the applied programs affect the psychomotor development areas of pre-school children at medium size. Based on these results, it is recommended to carry out studies concerning other development areas of pre-school children.

Keywords: Psychomotor development, pre-school, meta-analysis

\footnotetext{
${ }^{1}$ Bu çalışma, birinci yazarın hazırlamakta olduğu doktora tezinin bir kısmından üretilmiştir.
} 


\section{Giriş}

Okul öncesi yılları insan hayatının bütün gelişim alanlarının temelini oluşturan bir dönemdir. $\mathrm{Bu}$ dönemde çocuğa sağlanacak yaşantıların türü ve kalitesi, büyük oranda yetişkinin ona verebileceği olanakların niteliğine bağlıdır (Oktay, 2007). Çocuklara sunulan kaliteli eğitimin erken yaşlardan itibaren başlamasının, çocukların gelişim düzeylerine (Akçay, 2016; Chambers, Cheung ve Slavin 2016; Erbay, 2008; Hungi ve Ngware, 2018; Kefi, 1999; Kuday, 2007; Lehrl, Kluczniok ve Rossbach, 2016; Lehrl, Kluczniok, Rossbach ve Anders, 2017; Li, Zhang, Hu, Burchinal, Fan ve Qin, 2019; Masrai, 2018; Morgan, 2019; OECD, 2017; Polat Unutkan, 2007; Singh ve Mukherjee, 2018; Taner ve Başal, 2005) ve temel eğitime başlama olgunluğuna (Güzel ve Özyurt, 2018; Gove, Dombrowski, King, Pressley ve Weatherholt, 2018; Kaminski, Good, Abbott, Latimer ve Warnock, 2018; Masrai, 2018; Zhang, 2017) katkı yapması nedeni ile gelişmiş ülkelerin birçoğu okul öncesi eğitim okullaşma oranını \%90'ın üzerine çıkarmışlardır (OECD, 2017). Gelişmiş ülkelerde yakalanan yüksek okullaşma oranı sayesinde erken dönemde çocukların gelişimleri desteklenmektedir.

Okul öncesi eğitim politikaları ile ilgili son yıllardaki eğilim her çocuğun erken yaştan itibaren nitelikli eğitim ortamlarında bulunması gerektiği üzerinde yoğunlaşmaktadır. Kaliteli okul öncesi eğitim hizmetlerinin nasıl olması gerektiği ile ilgili çalışmalar hükümetlerin ilgili birimleri, sivil toplum kuruluşları ve birçok farklı disiplinden akademisyenlerin yoğun çalışmaları sonucunda şekillenmektedir. Çocukların hangi gelişim alanlarında nasıl desteklenmesi gerektiği ile ilgili birçok eğitim modeli, yaklaşım ve program önerisi bulunmaktadır. Bu öneriler tek bir gelişim alanının desteklenmesini içeren bir eğitim programı ya da çocukların bütün gelişim alanlarına katkı sağlayan bir model olabilir. Çocukların gelişim alanlarına yönelik farklı sınıflamalar olmakla birlikte genel olarak bilişsel, sosyal duygusal ve psikomotor gelişim olarak üç alanda ele alınmaktadır (Berk, 2013). Gelişim alanları keskin çizgilerle birbirinden ayrılamayacak kadar iç içe geçmiştir. Bir gelişim alanındaki herhangi olumlu ya da olumsuz bir durum diğer gelişim alanına etki edebilmektedir. Örneğin psikomotor gelişim alanındaki bir gelişim bozukluğu çocuğu çeşitli yaşam deneyimlerinden geri bırakacağından bilişsel ya da sosyal duygusal gelişim ile ilgili olumsuzluklara da neden olmaktadir.

Öneride bulunulan bir model ya da yaklaşım genellikle çocukların bütünsel gelişimine odaklanırken çeşitli eğitim programları bir ya da birkaç gelişim alanına etkiyi amaçlamaktadır. Fiziksel, bilişsel ve sosyal duygusal gelişimlere paralel olarak gelişen psikomotor gelişim, bireyin (çocuğun) kol, bacak gibi uzuvlarının bütün organları ile koordineli bir duruma gelmesi, hareketlerin denetim altına alınması ve bu hareketlerin becerikli bir şekilde yapılabilmesini ifade eder (Yeşilyaprak, 2006). Psikomotor gelişim; insan bedeninde büyüme ve olgunlaşmaya bağlı olarak gerçekleşen değişimleri içerir. Motor becerilerdeki gelişim, beyin ve motor koordinasyon ve bir takım hormonal etkiler psikomotor gelişim alanında incelenmektedir.

Psikomotor gelişim sinir-kas sistemlerindeki gelişimle yakından ilgilidir. Özellikle bebeklik dönemindeki refleksif hareketler, bebeklerin sinir kas gelişimlerinin önemli göstergesi olarak kabul edilmektedir. Refleksler ile başlayan psikomotor gelişim sinir-kas sistemindeki olgunlaşma neticesinde duruşa yönelik hareketler, yer değiştirmeye yönelik hareketler, koşma, atlama, denge hareketleri şeklinde ilerlemektedir. Çocukların motor gelişimi de bir sıra izler. Bu sıra merkezden (içten) dışarıya ve baştan ayağa doğrudur. Bütün gelişim alanlarında olduğu gibi psikomotor gelişim alanı da dönemler halinde ele alınmaktadır.

Gallahue tarafından öne sürülen motor gelişim dönemleri refleksif hareketler, ilkel hareketler, temel hareketler ve sporla ilişkili hareketler olarak isimlendirilmektedir. Gallahue psikomotor gelişim alanı dönemlerini çocukluk dönemi ile sınırlayarak incelemiş̧ir. Sahip olduğu kuramı da piramit modeli ile açılayarak bütün motor gelişim dönemini bir diğerinin üzerine inşa etmiştir (Gallahue, 1982). Çocukların psikomotor gelişimlerinin nasıl desteklenmesi gerektiği ile ilgili de birçok çalışma yürütülmektedir. Yürütülen bilimsel araştırmalar ebeveyn (Akgül, Yazıcı ve Akman, 2019; Ceylan, 2019; Ihmeideh; 2019; Karahan, 2019; Rodriguez, 2019) ya da öğretmen görüşlerini (Çullu ve Güleç, 2019; Hedlin, 2019; Vardi ve Demiriz, 2019; Yılmaz Bolat, 2019) içeren betimsel çalışmalar olabileceği gibi eğitimsel müdahaleleri içeren deneysel çalışmalar (Akgün; 2019; Cohrdes, Grolig ve Schroeder, 2019; Dickinson vd., 2019; Dilek; 2019; Tatlıpınar ve Serçe, 2019) da olabilmektedir. 
Bilim insanları tarafından yürütülen bilimsel çalışmalar toplumun gelişmesinde önemli bir rol oynamaktadır. Birçok bilim alanında olduğu gibi eğitim öğretim alanında da yapılan bilimsel çalışmalar eğitimin kalitesinin artırılması açısından önem arz etmektedir. Yapılan bilimsel çalışmalar neticesinde bütün dünyada bilim insanları her gün binlerce makale, tez, bildiri ve kitap yayımlamaktadır. Türkiye'de sadece 2019 yılında 72,527 lisansüstü tez tamamlanmıştır (YÖK, 2020). Bu sayı yaklaşık olarak günde 200 tezin yayınlanması anlamına gelmektedir. Bilimsel bilgi her geçen gün katlanarak büyümektedir. Yapılan bilimsel çalışma sayısı arttıkça kapsamlı ve sistematik araştırma sentezlerine olan ihtiyaç da artmaktadır. Yapılan bireysel çalışmaların sentezlenmesi için kullanılan en etkili yöntemlerden biri meta-analizdir.

Meta-analiz, yöntemleri ve sonuçları farklı, hatta birbirleriyle çelişen araştırmaların sayısal sonuçlarının birleştirilmesi anlamına gelmektedir. Meta-analiz araştırmacılara, analize dâhil ettikleri çalışmaların hiç birinden elde edemeyecekleri kadar net sonuçlar elde etmelerine olanak sağlar (Hunt, 1997). Borenstein, Hedges, Higgins ve Rothstein (2013) meta-analizi "çalışma serilerindeki sonuçların istatistiksel olarak sentezlenmesi” şeklinde tanımlamışlardır.

Türkiye'deki okul öncesi eğitimi alan yazını incelendiğinde çocukların gelişim alanlarını destekleyici eğitimsel müdahaleleri içeren bireysel çalışmalara rastlanmaktadır (Borre, Bernhard, Bleiker ve Winsler, 2013; Cohrdes, Grolig ve Schroeder, 2019; Gözüm ve Kandır; 2019; Özbey ve Köyceğiz, 2019; Üstündă̆ ve Ergin; 2020). Fakat bu müdahale programlarının çocukların gelişimlerine etkisinin ne olduğunu ortaya koymayı amaçlayan meta-analiz çalışmasına rastlanmamıştır. Farklı çalışma gruplarıyla yapılmış deneysel müdahalelerin çocukların gelişimlerine ne derece etki ettiğini ortaya koymak için yapılacak olan bir meta-analiz çalışmasının genel resmi görmek açısından önemli olduğu düşünülmektedir.

Bu nedenle bu araştırmada Türkiye'de 1998-2020 yılları arasında yayımlanan ve psikomotor gelişim alanını desteklediği belirtilen lisansüstü tezlerin amaç, yöntem ve sonuçları incelenmiştir. Araştırma kapsamında lisansüstü tezlerde okul öncesi dönem çocuklarına uygulanan eğitim amaçlı deneysel müdahalelerin okul öncesi dönem çocuklarının psikomotor alandaki gelişimlerine etki düzeyinin ortaya konulması amaçlanmıştır. Bu amaç doğrultusunda aşağıdaki soruların yanıtları aranmıştır:

1. Okul öncesi dönem çocuklarına uygulanan eğitim programları nelerdir?

2. Okul öncesi dönem çocuklarına lisansüstü tezler kapsamında uygulanan eğitim programlarının çocukların psikomotor gelişimlerine etkisi nedir?

\section{Yöntem}

Bu bölümde araştırmanın modeli, çalışma grubu, veri toplama aracı, veri toplama süreci ve verilerin analizine yer verilmiştir.

\section{Araştırmanın Modeli}

Araştırmada sistematik sentezleme yöntemlerinden biri olan meta-analiz yöntemi kullanılmıştır. Meta-analiz birbirinden bağımsız bireysel çalışmalardan elde edilen bulguların çeşitli istatistiksel teknikler kullanılarak sentezlenmesi ve yorumlanmasıdır. Meta-analizin amacı gerçekleri ortaya çıkarabilmek için farklı yer ve zamanlarda, aynı konuda yapılmış çalışmalardan elde edilen bulguları birleştirmek ve örneklem büyüklügünü artırmak yoluyla niceliksel olarak en doğruya ulaşabilmektir (Cumming, 2012).

\section{Çalışma Grubu}

Araştırmanın çalışma grubunu Türkiye'de 1998 ile 2020 yılının Mart ayı (15/03/2020 tarihinde tarama sonlandırılmıştır) arasında yapılan, okul öncesi dönemdeki çocukların psikomotor gelişimlerini desteklemeye yönelik olarak gerçekleştirilen eğitimsel müdahaleleri içeren 28 lisansüstü tez oluşturmaktadır. Deneysel desende tasarlanmış bu tezlerden 19'u yükssek lisans 9'u doktora tezidir. sunulmuştur.

Araştırmaya dâhil edilen çalışmaların seçiminde kullanılan kriterler dört maddede aşağıda

1. Kriter: Meta-analize 1998-2020 yılları arasında yayınlanmış olan çalışmalar. 
2. Kriter: Türkiye'de normal gelişim gösteren okul öncesi dönem çocukları ile psikomotor gelişimi desteklemek amacıyla uygulanan eğitimsel müdahale programlarını içeren deneysel desende tasarlanmış yüksek lisans ve doktora tezleri.

3. Kriter: Meta-analiz çalışmasında gerekli olan etki büyüklüklerinin hesaplanabilmesi için çalışmaya dâhil edilen araştırmaların betimleyici sayısal verilerine ihtiyaç duyulur. $\mathrm{Bu}$ nedenle örneklem büyüklüğü, aritmetik ortalama ve standart sapma değerlerini içeren çalışmalar araştırmaya dâhil edilmiştir.

Araştırmaya alınan tezlerin betimsel özelliklerine (program düzeyi, uygulamanın yapıldığı yerleşim yeri, okul türü ve yıl) göre frekans ve yüzdeleri Tablo 1'de, tezlerin uygulamalarının yapıldığı il ve yayınlandığı üniversitelere göre dağılımı Tablo 2'de sunulmuştur.

Tablo 1.

Tezlerin Lisansüstü Program Düzeyi, Uygulamanın Yapıldığı Yerleşim Yeri Okul Türü ve Y1llara Göre Frekans ve Yüzdeleri

\begin{tabular}{lcc}
\hline Lisansüstü Program Düzeyi & $\boldsymbol{f}$ & $\boldsymbol{\%}$ \\
\hline Yüksek lisans & 19 & 67.86 \\
\hline Doktora & 9 & 32.14 \\
\hline Uygulamanın Yapıldı̆̆ı Yerleşim Yeri & & \\
\hline İl merkezi & 26 & 92.86 \\
\hline İlçe merkezi & 2 & 7.14 \\
\hline Uygulamanın Yapıldığı Okul Türü & & 50.00 \\
\hline Kamu bağımsız & 14 & 28.57 \\
\hline Kamu ilköğretime bağlı & 8 & 17.86 \\
\hline Özel bağımsız & 5 & 3.57 \\
\hline Kamu/özel bağımsız & 1 & 3.57 \\
\hline Yıl & & 3.57 \\
\hline 2002 & 1 & 10.71 \\
\hline 2004 & 1 & 7.14 \\
\hline 2006 & 3 & 3.57 \\
\hline 2007 & 2 & 14.29 \\
\hline 2008 & 1 & 3.57 \\
\hline 2009 & 4 & 10.71 \\
\hline 2010 & 1 & 7.14 \\
\hline 2011 & 3 & 10.71 \\
\hline 2012 & 2 & 3.57 \\
\hline 2014 & 3 & 10.71 \\
\hline 2016 & 1 & 10.71 \\
\hline 2018 & 3 & $\mathbf{1 0 0 . 0 0}$ \\
\hline 2019 & 3 & \\
\hline Toplam & $\mathbf{2 8}$ & \\
\hline & & \\
\hline
\end{tabular}

Tablo 1'de de görüldüğü gibi okul öncesi dönemdeki çocukların psikomotor gelişimini destekleyici müdahale programları içeren tezlerin \%67.86'sının yüksek lisans tezi olduğu görülmektedir. Ayrıca deneysel müdahalelerin \%92.86'sının yerleşim yeri olarak il merkezlerinde uygulandığı, ilçelerde çok az uygulama yapıldığı, köylerde ise hiç uygulama yapılmadığı anlaşılmaktadır. Uygulamanın yapıldığı okul türü açısından bakıldığında, lisansüstü tezlerdeki eğitim programlarının \%78.57 oranında kamuya ait olan okul öncesi eğitim kurumlarında uygulandığı belirlenmiştir. Okul öncesi dönem çocuklarının psikomotor gelişim alanını desteklemek için yapılan eğitimsel müdahale programlarının yıllara göre dağılımı incelendiğinde, en çok lisansüstü tezin 2009 yılında yayınlandığı, 2016 ve 2017 yılları hariç tutulduğunda son yıllarda bu alandaki tezlerin sayılarının artma eğiliminde olduğu söylenebilir. 
Tablo 2.

Tezlerin Yapıldığı İllere, Üniversitelere ve Anabilim Dallarına Göre Frekansları

\begin{tabular}{ll}
\hline İl & f \\
\hline Ankara & 8 \\
\hline İstanbul & 8 \\
\hline Kocaeli & 2 \\
\hline Aydın, Batman, Edirne, Elazı̆̆, İzmir, Karabük, Kayseri, & 1 \\
Nevşehir, Samsun, Şanlıurfa & \\
\hline Üniversite & 7 \\
\hline Marmara Üniversitesi & 6 \\
\hline Ankara Üniversitesi & 5 \\
\hline Gazi Üniversitesi & 1 \\
\hline Adnan Menderes, Aksaray, Frrat, Hacettepe, Karabük, Mersin, \\
Muğla, Sakarya, Selçuk, Trabzon Üniversitesi & \\
\hline Anabilim Dalı & 10 \\
\hline Beden Ĕgitimi ve Spor & 10 \\
\hline Çocuk Gelişimi ve Eğitimi & 7 \\
\hline Okul Öncesi & 1 \\
\hline Eğitim Bilimleri & $\mathbf{2 8}$ \\
\hline Toplam & \\
\hline
\end{tabular}

Tablo 2 incelendiğinde yapılan deneysel müdahalelerin çoğunlukla Ankara ve İstanbul olmak üzere 13 farklı şehirde gerçekleştirildiği görülmektedir. Ayrıca en çok tezin yayımlandığı üniversitenin Marmara Üniversitesi olduğu ve bu alandaki tezlerin büyük çoğunluğunun Marmara, Ankara ve Gazi üniversitelerinde yapıldığı sonucuna ulaşılmıştır. Tezlerin en çok 10'ar çalışmayla "Beden Eğitimi ve Spor" ile "Çocuk Gelişimi ve Eğitimi” ana bilim dallarında yapıldı̆̆ı görülmektedir.

\section{Veri Toplama Aracı}

Araştırma kapsamına alınan çalışmaların gruplanması ve daha sonraki aşamalarda istenilen verilere kolayca ulaşılabilmesi amacı ile araştırmacı tarafından "Kodlama Formu" oluşturulmuştur. Kodlama formu üç başlık altında hazırlanmıştır. Çalışma kimliği, çalışma içeriği, çalışma verileri belirlenen alt başlıklardandır. Çalışma kimliği kapsamında çalışmanın adı, tez numarası, yazarı, yılı, yapıldığı üniversite/enstitü ve tez türüne yer verilmiştir. Çalışma içeriği bölümü çalışmanın adı, uygulama süresi (hafta, gün, dakika), uygulama yapılan okul türü (kamu/özel, bağımsız/ilköğretime bağlı), uygulamanın yapıldığı şehir, uygulamanın yapıldığı yerleşim yeri (il merkezi/ilçe merkezi/köy), örnekleme alınan çocukların yaş grubu (ay cinsinden), veri toplama aracı, kullanılan analiz yöntemi ve müdahale sonucunda katkı sağlanan gelişim alanına yer verilmiştir. Son olarak çalışma verileri bölümünde ise tezlerde belirtilen deney ve kontrol grubuna ait meta-analiz çalışmasında istatistiksel işlemlerin yapılabilmesi için gerekli veriler (örneklem büyüklükleri, aritmetik ortalama, standart sapma vb.) bulunmaktadır. Kodlama formu okul öncesi eğitimi alanında beş, ölçme ve değerlendirme alanında iki akademisyenden görüş alındıktan sonra uygulamaya hazır hale getirilmiştir.

\section{Veri Toplama Süreci}

Araştırmaya yönelik ilk önce pilot tarama yapılmış ve bu tarama sonucunda veri doygunluğu tespit edilmiştir. Pilot taramadan elde edilen tezler künyeleri üzerinden incelenmiş fakat araştırma kapsamına girdiği halde tarama sonuçları içerisinde yer almayan çalışmalar tespit edilmiştir. $\mathrm{Bu}$ eksikliğin tezlerde kullanılan anahtar kelimelerdeki farklılıklardan kaynaklandığı anlaşılmıştır. Örneğin bazı tezlerin anahtar kelimelerinde "psikomotor", "psikomotor gelişim", "motor", "motor gelişim", "fiziksel gelişim", "fizik gelişim", "bedensel gelişim", "sosyal duygusal gelişim" gibi farklılıklar olduğu tespit edilmiştir. Veri kaybı yaşanmaması adına yeni yapılan gelişmiş taramada aranacak alanların (yazar, danışman, konu, dizin, özet) tümü seçeneği kullanılarak 1998-2019 yılları arasında tarama yapılmıştır. Araştırmaya yönelik ilk tarama 2019 yılı haziran ayında, ikinci tarama 2020 yılı mart ayında Ulusal Tez Merkezi üzerinden çeşitli anahtar kelimeler kullanılarak yapılmıştır. Taramada ikili anahtar kelime kombinasyonları kullanılmıştır. Kullanılan ilk anahtar kelime "sadece yazılan şekilde", ikinci anahtar kelime ise "içinde geçsin" seçenekleri seçilerek ve "ve" bağlacı 
kullanılarak taranmıştır. İlk taramada "okul öncesi” ve "deney”, "okulöncesi” ve "deney”, "anasınıfi” ve "deney", "ana sinıfi" ve "deney", "erken çocukluk" ve "deney" ve son olarak "erken çocukluk eğitimi" ve "deney" anahtar kelimeleri ile toplamda 980 teze ulaşılmıştır.

Kodlama güvenirliğinin sağlanması, meta-analiz çalışmalarında özellikle önerilmektedir (Card, 2012). Kodlama güvenirliğinin analizi için elde edilen tezlerden çalışmanın dâhil edilme kriterlerine uygun olan ve rastgele seçilen 10 tez okul öncesi eğitim alanında biri yüksek lisans diğeri doktora mezunu iki uzmana kodlama formu ile birlikte mail ortamında gönderilmiştir. Uzmanlar ile araştırmanın amacı ve yapısı, kodlama formunun doldurulması hakkında 1 saat süren yüz yüze bir görüşme gerçekleştirilmiştir. Belirlenen 10 tez bir hafta süre zarfinda iki uzman ve araştırmacı tarafindan ayrı ayrı kodlama tablosuna girilmiştir. Kodlama işleminden sonra, kodlayıcılar arasındaki güvenirliği belirlemek için "uzlaşma sayısı/uzlaşma+uzlaşmama sayısı” formülünden yararlanılmıştır. Kodlayıcılar arasındaki uygunluğun \%70'in üzerinde olması güvenirliğin yeterli olduğunu göstermektedir (Tavşancıl ve Aslan, 2001). Yapılan hesaplama sonucunda araştırmacı ile birinci uzman arasında \%99, ikinci uzman arasında \%98 uygunluk tespit edilmiştir.

Kodlayıcı güvenirliğinin makul olduğunun anlaşılmasının ardından kodlama tablosuna veri girişi yapılmaya başlanmıştır. 2020 yılının mart ayında veri girişinin tamamlanmasının ardından 2019 yılının temmuz ayı ile 2020 yılının mart ayı arasında yayınlanan tezlere ulaşmak amacıyla aynı anahtar kelimeler kullanılarak yeniden tarama yapılmıştır. Bu yeni taramada 200 teze ulaşılmıştır. İki taramadan elde edilen 1180 tez içerisinden psikomotor gelișim alanındaki 28 teze indirgenme sürecini içeren akış diyagramı Şekil 1'de yer almaktadır. Araştırmaya dâhil edilen lisansüstü tezlere yönelik kaynakça Ek 1'de yer almaktadır.
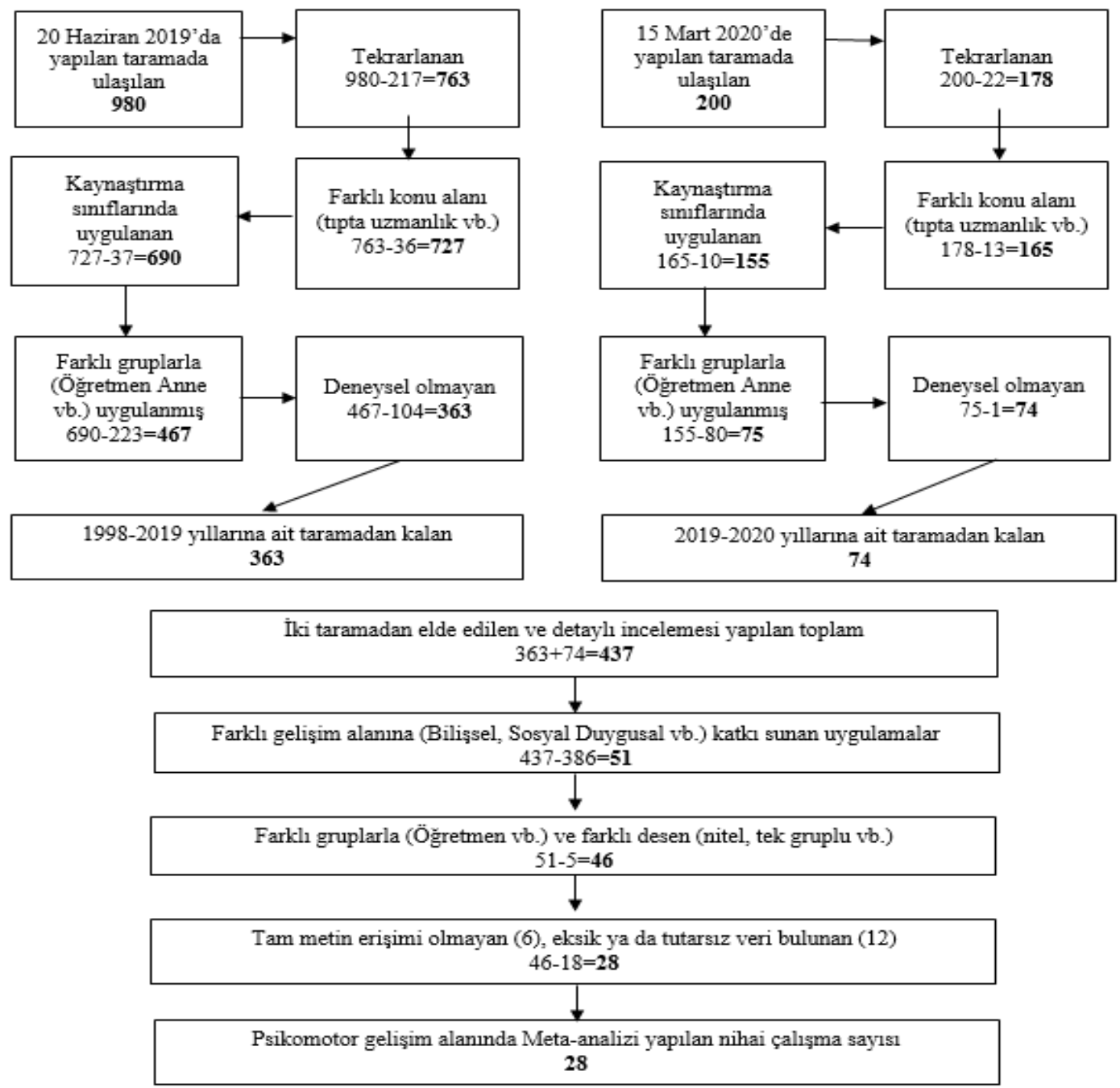

Şekil 1. Veri Toplama Süreci Akış Diyagramı 


\section{Verilerin Analizi}

Araştırmaya dâhil edilen tezlerden elde edilen verilerin analizinde Comprehensive MetaAnalysis V3.0 (CMA) yazılımı deneme kopyasından faydalanılmıştır. Aritmetik ortalama, standart sapma ve örneklem büyüklükleri gibi veriler ışığında uygun istatistiksel işlemler yapılmıştır. Araştırma kapsamına alınan tezlerde 0.05 anlamlılık düzeyi benimsendiğinden verilerin istatistiksel analizlerinde anlamlılık düzeyi olarak 0.05 belirlenmiştir.

Meta-analiz çalışmasında kullanılabilecek etki büyüklükleri (ES) araştırma sorularına ve yapılarına göre çeşitlilik göstermektedir. Sosyal bilimler alanında yapılan çalışmalarda genellikle grup (deney ve kontrol) karşılaştırmaları ve ilişkisel (korelasyon) karşılaştırmalar yapıldığından, etki büyüklüğ̈̈ olarak Cohen d ve Hedge's g ile korelasyon katsayısı r kullanılmaktadır (Kış, 2013). Bu araştırmada, verilerin analizinde, grup karşılaştııılması için kullanılan meta-analiz türlerinden grup farklılığı yöntemi kullanılmıştır. Çalışmadaki bağımsız değişkenlere ait aritmetik ortalama ve standart sapma değerleri aynı ölçeklerden alınmadığı durumlarda standartlaştırılmış aritmetik ortalamalar farkı etki büyüklüğü yöntemi kullanılır (Card, 2012). Bu araştırmada standartlaştırılmış aritmetik ortalamalar farkını ifade etmek üzere her bir çalışma için Hedge's g etki büyüklüğü indeksi hesaplanarak meta-analiz sonucunda ortak etki büyüklüğüne ulaşılmıştır.

Bu araştırmadaki etki büyüklüğü değeri alan yazında sıklıkla kullanılan, aritmetik ortalamalara dayanan Cohen (1988)'in sinıflandırması ile değerlendirilmiştir. Bu sınıflandırmaya göre etki büyüklüğü değeri $\mathrm{d}=0.20-0.50$ arasında ise düşük düzeyde (small), $\mathrm{d}=0.50-0.80$ arasında ise orta düzeyde (medium), $\mathrm{d}=0.80$ 'den büyük ise yüksek düzeyde (large) etkiyi ifade etmektedir.

\section{Bulgular}

$\mathrm{Bu}$ bölümde öncelikle meta-analize dâhil edilecek çalışmalar için yayın yanlılı̆̆ 1 olup olmadığı test edilmiştir. Yayın yanlılığı pozitif ve istatistiksel olarak anlamlılık bulunan çalışmaların negatif ya da istatistiksel anlamlılık bulunmayan çalışmalara göre yayınlanma eğiliminin daha yüksek olduğu anlamına gelmektedir (Borenstein, Hedges, Higgins ve Rothstein, 2013). Daha sonra lisansüstü tezlerde uygulanan eğitimsel müdahale programlarının okul öncesi dönem çocuklarının psikomotor gelişimlerine etkisini belirlemek amaciyla orman grafiği oluşturulmuş, hetorojenlik ve rastgele etkiler modeli bulguları sunulmuştur.

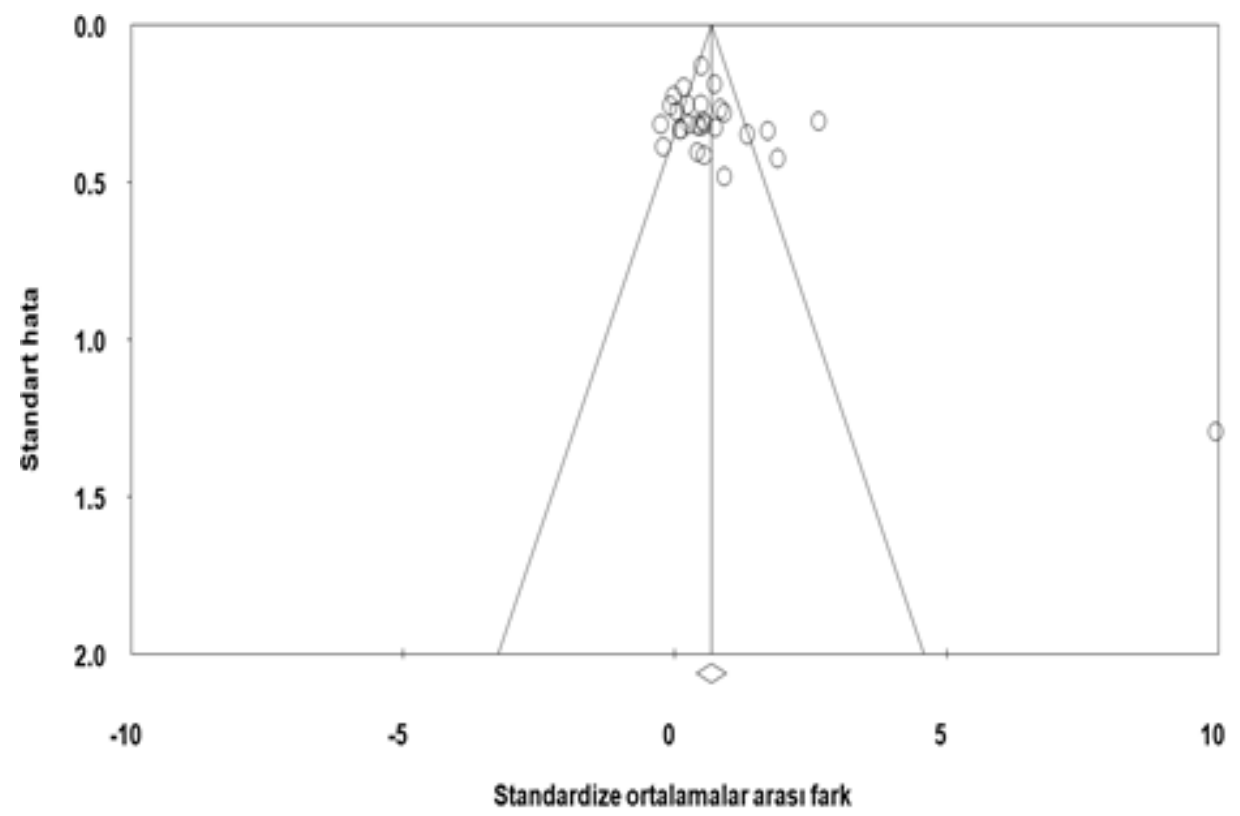

Şekil 2. Çocukların Psikomotor Gelişimlerine Katkı Sağlayan Tezlerin Huni Saçılım Grafiği

Şekil 2'de görüldüğü gibi araştırmaya dâhil edilen 28 adet tezin büyük bir çoğunluğu şeklin üst kısmında ve birleştirilmiş etki büyüklügüne çok yakın bir konumda yer almaktadır. Huni grafiğinde bireysel çalışmaların simetrik olarak dağılması ve üst kısımlarda yer alması yayın yanlılı̆̆ının olmadığını göstermektedir. 


\begin{tabular}{|c|c|c|c|c|c|c|c|}
\hline Çalışma & $\begin{array}{l}\text { Standardize } \\
\text { ortalamalar } \\
\text { fark। }\end{array}$ & $\begin{array}{l}\text { Standart } \\
\text { hata }\end{array}$ & Varyans & $\begin{array}{l}\text { Alt } \\
\text { limit }\end{array}$ & $\begin{array}{l}\text { Üst } \\
\text { limit }\end{array}$ & $\mathbf{z}$ & $\mathrm{p}$ \\
\hline Akgün (2019) & 0.42 & 0.32 & 0.10 & -0.21 & 1.04 & 1.31 & 0.19 \\
\hline Akınbay (2014) & 0.17 & 0.20 & 0.04 & -0.22 & 0.57 & 0.87 & .38 \\
\hline Altınkök (2006) & 0.84 & 0.27 & 0.07 & 0.31 & 1.37 & 3.12 & .00 \\
\hline Beken (2009) & 9.97 & 1.30 & 1.68 & 7.43 & 12.50 & 7.70 & 0 \\
\hline Beyazıt (2012) & 0.92 & 0.28 & 0.08 & 0.37 & 1.47 & 3.27 & .00 \\
\hline $\mathrm{Boz}(2011)$ & 0.73 & 0.19 & 0.04 & 0.37 & 1.10 & 3.90 & 00 \\
\hline Çelik Arslan (2012) & -0.08 & 0.26 & 0.07 & -0.59 & 0.43 & -0.31 & \\
\hline & 0.13 & & 0.11 & -0.53 & 0.78 & 0.38 & \\
\hline Ercan (2009) & -0.01 & 0.23 & 0.05 & -0.45 & 0.44 & -0.03 & 0.97 \\
\hline Erdemir (2009) & 0.93 & 0.48 & 0.23 & -0.02 & 1.87 & 1.92 & 0.06 \\
\hline & 0.05 & 0.28 & 0.08 & -0.50 & 0.59 & 0.16 & 0.87 \\
\hline Gül (2006) & 0.55 & 0.42 & 0.17 & -0.26 & 1.37 & 1.32 & \\
\hline Karaman (2019) & 0.55 & 0.32 & 0.10 & -0.07 & 1.18 & 1.73 & .08 \\
\hline Kılıç (2 & 1.91 & 0.43 & 0.18 & 1.07 & 2.74 & 4.47 & 0.0 \\
\hline 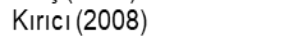 & 0.50 & 0.13 & 0.02 & 0.25 & 0.76 & 3.84 & \\
\hline Mülazımoğlu Ballı (2006) & 6) 0.49 & 0.25 & 0.06 & -0.01 & 0.99 & 1.94 & 0.05 \\
\hline & 1.34 & & 0.12 & & & & \\
\hline Özd & 0.48 & 0.3 & 0.11 & -0.15 & 1.12 & 1.49 & \\
\hline Öztürk (2009) & -0.25 & 0.32 & 0.10 & -0.87 & 0.37 & -0.78 & \\
\hline Sarıtas (2010) & 2.65 & 0.31 & 0.09 & 2.05 & 3.25 & 8.65 & \\
\hline Erdoğan (2014) & 4) 0.55 & 0.31 & 0.09 & -0.06 & 1.15 & 1.78 & \\
\hline $\operatorname{Sen}(2004)$ & 0.75 & 0.33 & 0.11 & 0.11 & 1.39 & 2.30 & 0.0 \\
\hline Taştepe (2018) & 0.42 & 0.40 & 0.16 & -0.37 & 1.22 & 1.04 & 0.30 \\
\hline Toran (2011) & 1.72 & 0.34 & 0.11 & 1.06 & 2.38 & 5.09 & \\
\hline Tuzcuoğlu (2007) & 0.11 & 0.33 & 0.11 & -0.55 & 0.76 & 0.3 & \\
\hline Tüfekçioğlu (2002) & 0.24 & 0.26 & 0.07 & -0.26 & 0.74 & 0.95 & \\
\hline Türel (2019) & -0.20 & 0.39 & 0.15 & -0.97 & 0.56 & -0.53 & 0.60 \\
\hline \multirow[t]{2}{*}{ Yavuz (2016) } & & 0.32 & 0.10 & -0.35 & 0.90 & 0.87 & \\
\hline & 0.67 & 0.14 & 0.02 & 0.40 & 0.94 & 4.90 & \\
\hline
\end{tabular}

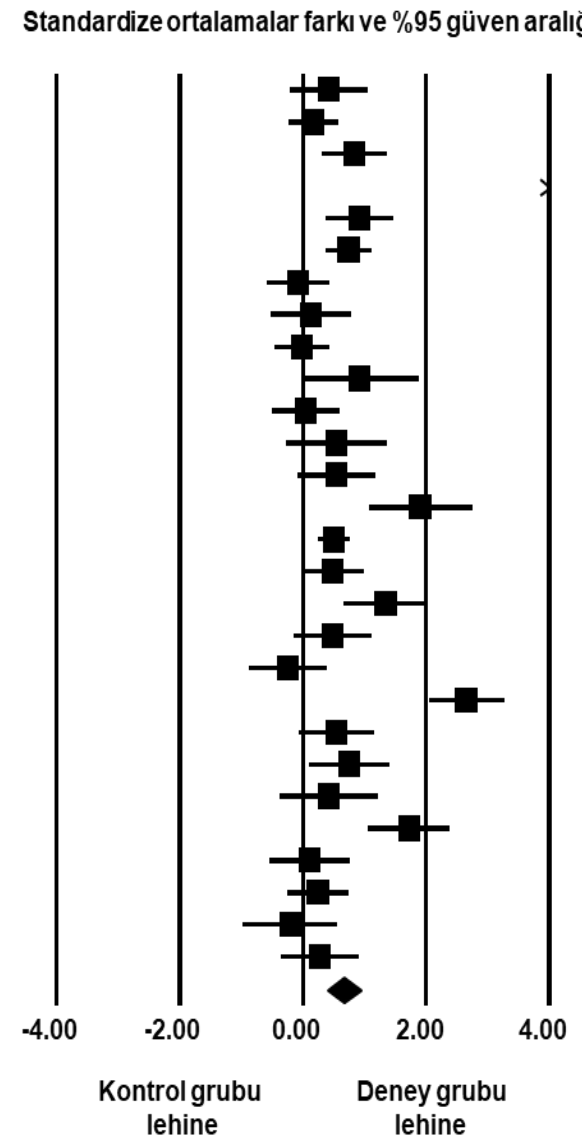

Şekil 3. Çocukların Psikomotor Gelişimlerine Katkı Sağlayan Tezlerin Etki Büyüklükleri Orman Grafiği

Şekil 3'de yer alan orman diyagramına göre etki büyüklükleri birleştirilen 28 tezin ortak etki büyüklüğ̈̈ 0.671 olarak hesaplanmıştır. Tezler arası heterojenliğin belirlenmesinde Cochrane's Q istatistiği ve $\mathrm{I}^{2}$ indeksinden yararlanılmıştır. $\mathrm{I}^{2}$ istatistiği $\% 25$ 'in altında olduğunda düşük, \%25-50 arasında olduğunda orta, \%50'nin üzerinde olduğunda yüksek heterojenlik bulunduğu şeklinde yorumlanmıştır (Patsopoulos, Evangelo ve Ioannidis, 2008). Modelin heterojenlik değerlendirmesinde $\mathrm{I}^{2}$ değeri 83.83 olarak bulunmuş ve tezler arası heterojenlik olduğu belirlenmiştir. Ayrıca Q testine göre de modelin heterojen yapıda olduğu görülmüştür (Q: 166.98, p<0.001).

Tablo 3.

Çocukların Psikomotor Gelişimlerine Katkı Sağlayan Tezlerin Rastgele Etkiler Modeline Göre Birleștirilmiș Bulguları

\begin{tabular}{lccccccc}
\hline Çalışma & Etki Büyüklüğü & $\begin{array}{c}\text { Standart } \\
\text { Hata }\end{array}$ & Varyans & $\begin{array}{c}\text { Alt } \\
\text { sınır }\end{array}$ & Üst Sınır & Z & p \\
\hline $\begin{array}{l}\text { Rastgele } \\
\begin{array}{l}\text { Etkiler } \\
\text { Modeli }\end{array}\end{array}$ & 0.671 & 0.14 & 0.02 & 0.402 & 0.939 & 4.90 & $<0.001$ \\
\hline
\end{tabular}

Tablo 3'te, meta-analize dâhil edilen 28 tezdeki verilerin rastgele etkiler modeline göre sonuçları yer almaktadır. Bu sonuçlara göre; \%95'lik güven aralığının alt sınırı 0.402 ve üst sınırı 0.939 , standart hata 0.14 ve etki büyüklüğü değeri ise $\mathrm{ES}=0.671$ hesaplanmıştır. Deney grubundaki okul öncesi dönem çocuklarına yönelik uygulanan eğitimsel müdahalelerin çocukların psikomotor gelişimlerine istatistiksel olarak anlamlı düzeyde etki ettiği sonucunda varılmıştır. Hesaplamalar sonucunda elde edilen 0.671 'lik etki büyüklüğü değeri uygulanan eğitimsel müdahalelerin deney grubundaki çocuklarım psikomotor gelişimlerine Cohen'in standardize ortalamalar farkı için belirlediği etki büyüklüğü sınıflandırmasına göre orta düzeyde etkili olduğunu göstermektedir. 


\section{Tartışma, Sonuç ve Öneriler}

Türkiye'de 1998-2020 arasında yayımlanan, psikomotor gelişim alanını destekleyici eğitimsel müdahale içeren lisansüstü tezlerin sayısı diğer gelişim alanlarına nispeten daha az sayıda olsa da son on yılda bu alana yönelik yapılan tez sayılarında bir artış görülmektedir. Bu araştırmalar ile ilgili inceleme yapıldığında nitel ve nicel paradigmaya göre hazırlanmış anne-baba, öğretmen, öğretmen adayı ve yöneticiler ile yapılan çalışmaların yanı sıra kaynaştırma sınıflarında ya da özel gereksinimli çocuklara uygulanmış, betimsel, ilişkisel ya da deneysel birçok çalışma bulunmaktadır. Farklı yöntem ve gruplarla yapılmış olan çalışmalar bu araştırma kapsamı dışında tutulmuştur. Bu araştırmada okul öncesi dönem çocuklarına uygulanan eğitimsel müdahale programlarının psikomotor gelişimlerine etkisi üzerinde durulmuştur. Bu alanda yapılan lisansüstü tezlerin sonuçlarını sentezleyebilmek ve okul öncesi dönemdeki çocukların psikomotor gelişimleri konusunda yapılacak yeni çalışmalara bir yol gösterebilmek için bir meta-analize ihtiyaç duyulmuştur.

Araştırmaya dâhil edilen 28 teze ait örneklem sayısı 792'si deney grubu 783'ü kontrol grubu olmak üzere toplam 1575 'tir. Araştırma kapsamında incelenen tezlerin en çok Ankara ve İstanbul'da il merkezlerinde bulunan Milli Eğitim Bakanlığı'na bağlı kamu bağımsız anaokullarında gerçekleştirilen yüksek lisans tezleri olduğu görülmüştür. Çocukların psikomotor alandaki gelişimlerine destek olmak amacıyla yıl olarak en çok 2009 y1lında, üniversite olarak da Marmara Üniversitesi'nde tez yayımlanmıştır.

Araştırmaya dâhil edilen tezlerin yayın yanlılı̆̆ huni saçılım grafiği kullanılarak yapılmış ve herhangi bir yayın yanlılığının olmadığı belirlenmiştir. 1575 kişilik bir örneklemi oluşturan 28 çalışmaya ait etki büyüklükleri hesaplanmış, 17 çalışmada istatistiksel olarak anlamlılık bulunmazken 11 çalışmada anlamlı farklılık bulunmuştur. Rastgele etkiler modelinde birleştirme işlemi sonucu deney grubu lehine 0.671 'lik pozitif ve anlamlı bir etki büyüklügü bulunmuştur. Meta-analiz sonucunda hesaplanan ortak etki büyüklüğü değeri Cohen (1998)'e göre orta düzeyde ancak yüksek düzeye yakın bir sonuçtur. Yapılan heterojenlik $\left(\mathrm{Q}\right.$ ve $\left.\mathrm{I}^{2}\right)$ testleri sonucunda araştırma kapsamına alınan tezlerin heterojen yapıda olduğu bulunmuştur.

Sistematik sentezleme çeşitlerinden olan oy sayma yöntemi ile değerlendirildiğinde çalışmaların çoğunluğunda (\% 60.71'i) istatistiksel olarak anlamlı sonuca ulaşılmamıştır. Fakat bu 17 çalışmadan 13'ü istatistiksel olarak anlamlı olmasalar da deney grubu lehine sonuçları içermektedir. Oy sayma yöntemi kullanılarak yapılan değerlendirme ile meta-analiz yöntemi kullanılarak yapılan değerlendirme arasındaki çelişki oy sayma yönteminin zayıflı̆̆ını göstermektedir. Oy saymanın mantığı istatistiksel olarak anlamlı bulunmayan bulguların bir etkisinin olmadığı, yalnızca anlamlı olan bulguların etkisinin olduğu şeklindedir. İstatistiksel olarak anlamlı olmayan bulguların gücünün düşük olması nedeniyle anlamsız olarak değerlendirilebilmektedir (Borenstein, Hedges, Higgins ve Rothstein, 2013).

Bu sonuçlar birlikte değerlendirildiğinde okul öncesi dönem çocuklarına uygulanan eğitimsel müdahalelerin çocukların psikomotor gelişimlerine etkisi sosyal bilimler açısından önemli sayılabilecek bir düzeydedir. Lisansüstü tezlerde uygulanan eğitimsel müdahalelerin çocukların psikomotor gelişimlerine etkisinin olması beklenen bir sonuçtur. Alan yazın incelemesi sonucunda Türkiye'de okul öncesi dönem çocuklarının psikomotor gelişimlerini inceleyen bir meta-analiz çalışmasına rastlanmamıştır. Ancak yurt dışında bu konuda yapılmış önemli çalışmalar yer almaktadır. Alan yazındaki önceki yapılan çalışmalar ile bu araştırma sonuçları arasında benzerlik olduğu söylenebilir. Engel, Broderic, van Doorn, Hardly ve Parmenter (2018) tarafindan yapılan çocuklardaki temel motor beceri müdahalelerinin etkisi ile ilgili meta-analiz çalışmasında 14 bireysel çalışma incelenmiş̧ir. Meta-analiz sonucunda öğretmenler tarafından haftada üç ve daha fazla seans uygulanan fiziksel aktiviteleri içeren müdahalelerin çocukların temel motor becerilerinde düşük düzeyde $(\mathrm{ES}=0.23)$ etkisi olduğu ortaya konulmuştur. Diğer bir çalışmada, Capelle, Broderic, van Doorn ve Ward (2017) temel motor becerileri geliştirmeye yönelik müdahaleleri içeren 20 bireysel çalışmayı ele almışlardır. Araştırma sonucunda 3-5 yaş grubu çocuklara yönelik olarak öğretmen tarafindan uygulanan müdahalelerin küçük düzeyde $(\mathrm{ES}=0.13)$ etkisinin olduğunu saptamışlardır. Wick vd. (2017) tarafindan, 2-6 yaş arası çocuklara en az 4 hafta uygulanan temel motor becerileri geliştirmeye yönelik müdahalelerin olduğu çalışmalar incelenmiştir. Temel motor beceriler açısından, 4 veya 5 
hafta süre ile uygulanan müdahalelerin 6 hafta ve daha uzun süre uygulanan müdahalelere göre daha yüksek etki büyüklüğüne sahip olduğu saptanmıştır $(E S=1.43)$. Ayrıca alt gruplara özgü yapılan analizlerde uygulanan müdahalelerin, nesne kontrolü üzerinde (ES=1.36) ve lokomotor alt boyutu üzerinde (ES=1.91) büyük etkiye sahip olduğu saptanmıştır. Burns, Fu ve Podlog (2017)'nin okul temelli fiziksel aktivite müdahalelerinin öğrencilerin fiziksel aktivite zevkini artırmadaki etkinliğini incelemek amacıyla yaptıkları araştırmada 10 çalışma meta-analize dahil edilmiştir. Araştırma sonucunda fiziksel aktivite zevkini artırmaya yönelik okul temelli müdahalelerin etkisinin zayıf-orta büyüklükte $(\mathrm{ES}=0.38)$ olduğu saptanmıştır. Johnstone, Hughes, Martin ve Reilly (2018) aktif oyun müdahalelerinin çocukların fiziksel aktivite düzeyleri üzerindeki etkisininin belirlenmesini ortaya koymayı amaçlamışlardır. Çalışmada, 3-12 yaş arasındaki çocukları hedef alan çalışmaların sistematik derlemesi yapılmış, dört çalışma için meta-analiz yapılmıştır. Meta-analizde çalışma sayısının az olması ve bu çalışmaların heterojenliği nedeniyle aktif oyun müdahalelerinin çocukların fiziksel aktivite düzeyleri üzerindeki etkisi hakkında kesin sonuca varılamamıştır. Bu çalışmalara ek olarak fiziksel müdahale programlarının psikomotor gelişimlerine etkisinin yanında bilişsel gelişim ve akademik başarıya olan etkisinin incelendiği meta-analiz çalışmalarına da rastlanmıştır (AlvarezBueno vd. 2017; Alvarez-Bueno vd. 2020; de Greeffa, Boskerb, Oosterlaand, Visschera ve Hartman 2018; Vazou, Pesce, Lakes ve Smiley-Oyen, 2019).

Türkiye'deki lisansüstü tezlerde uygulanan eğitimsel müdahale programlarının okul öncesi dönem çocuklarının psikomotor gelişimlerine etkisini belirlemek amacıyla yapılan bu araştırmada 28 lisansüstü tez meta-analize dâhil edilmiştir. Meta-analiz sonucunda uygulanan programların çocukların psikomotor gelişimlerine orta düzeyde ancak yükseğe yakın bir etkisinin olduğu sonucuna varılmıştır. Araştırma bulgularına dayalı olarak, araştırmacılara okul öncesi dönem çocuklarının diğer gelişim alanlarını ilgilendiren çalışmaların yapılması önerilmektedir. Diğer bir öneri ise meta-analiz çalışmalarının önemli veri kaynaklarından olan lisansüstü tezlere erişim sağlama konusunda yaşanan güçlükler nedeniyle Ulusal Tez Merkezi'nin lisansüstü tezlerini erişime açmaları konusunda araştırmacıları teşvik etmesidir. Ayrıca meta-analiz yönteminin ülkemizdeki çalışmalarda daha yaygın ve etkili biçimde kullanılabilmesi için herhangi bir bilim alanında yapılmış çalışmaları (tez, makale ve bildiri) bir araya getiren, daha sistematik ve ulaşılabilir veri tabanlarının oluşturulması sağlanmalıdır. Bazı tezlerde meta- analiz için gerekli olan verilerde eksikliklerin olması sebebiyle yazarlar ile iletişim kurulması gerekmektedir. Yazarların iletişim bilgilerinin bulunmaması dolayısıyla yaşanan veri kayıplarının önüne geçmek için tezlere yazarın iletişim bilgilerini de içeren özgeçmişleri konulabilir. Bilimsel çalışmaların hazırlanmasına ve yayınlanmasına katkı sağlayan paydaşlar istatistiksel olarak anlamlı farklılık bulunmayan araştırma sonuçlarının da raporlaştırılmasına dikkat etmeli ayrıca araştırma raporlarında araştırmanın gereği olarak yapılan t testi ve $F$ testi sonuçları verilirken ortalama ve standart sapma değerlerinin de belirtilmesine özen göstermelidirler. 


\section{Kaynakça}

Akgül, E., Yazıc1, D. ve Akman, B. (2019). Views of parents preferring to raise a bilingual child. Early Child Development and Care, 189(10), 1588-1601.

Akgün, S. (2019). Hareket ĕgitimi ve imgelemenin okulöncesi eğitim kurumlarındaki 4-6 yaş çocuklarda motor gelişime etkisi (Yayınlanmamış Doktora Tezi). Trabzon: Trabzon Üniversitesi.

Akçay, A. (2016). Okulöncesi eğitimi almanın öğrencilerin dil becerilerinin gelişimine etkisi. Turkish Studies, 11(3), 15-28.

Alvarez-Bueno, C., Pesce, C., Cavero-Redondo I., Sanchez-Lopez, M., Garrido-Miguel, M. ve Martínez-Vizcaíno, V. (2017). Academic Achievement and Physical Activity: A Metaanalysis. Pediatrics, 140(6), :e20171498. doi: 10.1542/peds.20171498.

Álvarez-Bueno, C., Hillman, C. H., Cavero-Redondo, I., Sánchez-López, M., Pozuelo- Carrascosa, D. P. ve Martínez-Vizcaíno, V. (2020) Aerobic fitness and academic achievement: A systematic review and meta-analysis, Journal of Sports Sciences, 38(5), 582-589.

Berk, L. E. (2013). Bebekler ve çocuklar doğum öncesinden orta çocukluğa. Çeviri editörü: Işıkoğlu Erdoğan. Ankara: Nobel Akademi.

Borenstein, M., Hedges, L., Higgins, J. ve Rothstein, H. (2013). Meta-analize giriş. (Çev. S. Dinçer). Ankara: An1 Yayınc1lik.

Borre, A. J., Bernhard, J., Bleiker, C. ve Winsler, A. (2019). Preschool literacy intervention for lowincome, ethnically diverse children: Effects of the early authors program through kindergarten. Journal of Education for Students Placed at Risk (JESPAR), 24(2), 132-153.

Burns, R. D., Fu, Y. ve Podlog, L. W. (2017). School-based physical activity interventions and physical activity enjoyment: A meta-analysis. Preventive Medicine, 103, 84-90.

Camilli, G., Vargas, S., Ryan, S. ve Barnett, W. S. (2010). Meta-analysis of the effects of early education interventions on cognitive and social development. Teacher Colllege Reccord. 112, 579-620.

Capelle, A.V., Broderick, C. R., van Doorn N. ve Ward R. E. (2017). Parmenter, B. J. Interventions to improve fundamental motor skills in pre-school aged children: A systematic review and metaanalysis. Journal of Science and Medicine in Sport 20, 658-666.

Card, N. A. (2012). Applied meta-analysis for social science research. (T. D. Little, Ed.). New York: The Guilford Press.

Ceylan, R. (2019). Ebeveynlerin okul öncesi kurumu hakkındaki görüşleri: tercih sebepleri, beklentileri ve memnuniyetleri. Electronic Journal of Social Sciences, 18(70), 497-517.

Chambers, B., Cheung, A. C. ve Slavin, R. E. (2016). Literacy and language outcomes of comprehensive and developmental-constructivist approaches to early childhood education: A systematic review. Educational Research Review, 18, 88-111.

Cohen, J. (1988). Statistical power analysis for the behavioral sciences (2. bask1). New Jersey: Lawrence Erlbaum Associates, Inc.

Cohrdes, C., Grolig, L. ve Schroeder, S. (2019). The development of music competencies in preschool children: effects of a training program and the role of environmental factors. Psychology of Music, 47(3), 358-375.

Cumming, G. (2012). Understanding the new statistics. New York: Routledge, Taylor and Francis Group.

Çullu, F., ve Güleç, H. (2019). Okul öncesi öğretmenlerinin okul öncesi eğitimine yönelik görüşleri. Journal of International Social Research, 12(65).

Değirmenci, B. (2020). Yaratıcı drama temelli etkinliklerin okul öncesi çocukların problem çözme ve sosyal beceri düzeylerine etkisi (Yayınlanmamış Yüksek Lisans Tezi). Mersin: Çağ Üniversitesi. 
de Greeff, J. W., Bosker,R.J., Oosterlaan, J. Visscher, C. ve Hartman. E. (2018). Effects of physical activity on executive functions, attention and academic performance in preadolescent children: a meta-analysis. Journal of Science and Medicine in Sport, 21, 501-507.

Dickinson, D. K., Collins, M. F., Nesbitt, K., Toub, T. S., Hassinger-Das, B., Hadley, E. B.,HirshPasek, K. ve Golinkoff, R. M. (2019). Effects of teacher-delivered book reading and play on vocabulary learning and self-regulation among low-income preschool children. Journal of Cognition and Development, 20(2), 136-164.

Dilek, Ö. (2019). Orman okulu uygulamalarının çocukların gelişimine yönelik katkısının değerlendirilmesi (Yayınlanmamış Doktora Tezi). Kastamonu: Kastamonu Üniversitesi.

Engel, A. C., Broderick, C. R., van Doorn, N., Hardy, L. L. ve Parmenter, B. J. (2018). Exploring the relationship between fundamental motor skill interventions and physical activity levels in children: A systematic review and meta-analysis. Sports Medicine, 48(8), 1845-1857.

Erbay, E. (2008). Okul öncesi eğitim alan ve almayan ilköğretim birinci sinıf öğrencilerinin sosyal becerilere sahip olma düzeyleri. (Yayınlanmamış Yüksek Lisans Tezi). Denizli: Pamukkale Üniversitesi.

Gallahue, D. (1982). Understanding motor development in children. New York: John Wileyand Son.

Gove, A., Dombrowski, E., King, S. J., Pressley, J. ve Weatherholt, T. (2018). Persistence and fadeout of preschool participation effects on early reading skills in low-and middleincome countries. Global Education Review, 5(2), 85-109.

Gözüm, A. İ. C. ve Kandır, A. (2019). Attention Skill Development Program's Effects on Children in Terms of Attention Skill Acquisition during Preschool Term= Okul öncesi dönemde dikkat yetisinin gelişimi programının çocukların dikkat yetisi kazanımına etkisi. Pegem Journal of Education and Instruction, 9(2), 547-584.

Güzel, N. ve Özyurt, M. (2018). Okul öncesi eğitimi alan çocukların okul olgunluğu düzeylerinin ve okul olgunluğuna ilişkin öğretmen görüşlerinin incelenmesi. Mersin Üniversitesi Eğitim Fakültesi Dergisi, 14(3), 1250-1267.

Hedlin, M. (2019). 'They only see their own child': an interview study of preschool teachers' perceptions about parents. Early Child Development and Care, 189(11), 1776-1785.

Hungi, N. ve Ngware, M. (2018). The effects of preschool participation on mathematics achievement of Grade 6 pupils in Uganda. Educational Research for Policy and Practice, 17(2), 105-126.

Johnstone, A., Hughes, A., R. Martin, A. ve Reilly, J. J. (2018). Utilising active play interventions to promote physical activity and improve fundamental movement skills in children: a systematic review and meta-analysis. BMC Public Health, 18, 789.

Ihmeideh, F. (2019). Getting parents involved in children's play: Qatari parents' perceptions of and engagement with their children's play. International Journal of Primary, Elementary and Early Years Education, 47(1), 47-63.

Kaminski, R. A., Good III, R. H., Abbott, M., Latimer, R. ve Warnock, A. (2018). Effectiveness of preschool and kindergarten in promoting and maintaining early literacy skills. Poster session presented at the National Research Conference on Early Childhood, Arlington, VA. https://acadiencelearning. org/papers/PELI_handout_NRCEC_2018. pdf. adresinden alınmıştır.

Karahan, S. (2019). Okul öncesindeki özel gereksinimli çocukların sosyal becerilerine ilişkin anne, baba ve ögretmen görüşleri: Karma yöntem çalışması. (Yayınlanmamış Yüksek Lisans Tezi). Gaziantep: Hasan Kalyoncu Üniversitesi.

Kefi, S. (2004) Okul öncesi eğitim kurumlarına devam eden 36-72 aylık öğrencilerin dil gelişimi düzeylerine bu kurumlarda high-scope modeli eğitim almalartyla klasik model ĕgitim almalarının etkisinin incelenmesi. Omep Dünya Konsey Toplantısı ve Konferansında sunulan bildiri, İstanbul.

Kış, A. (2013). Okul müdürlerinin öğretimsel liderlik davranışlarını gösterme düzeylerine ilişkin yönetici ve ögretmen görüşlerine yönelik bir meta-analiz (Yayınlanmamış Doktora Tezi). Malatya: İnönü Üniversitesi. 
Kuday, F. S. (2007). Aile destekli kurum merkezli eğitim alan ve hiç okul öncesi eğitim almayan 3-6 yaş çocukların bilişssel geliş̧imlerinin karşılaş̧ırılması. (Yayınlanmamış Yüksek Lisans Tezi). İstanbul: Marmara Üniversitesi.

Lehrl, S., Kluczniok, K. ve Rossbach, H. G. (2016). Longer-term associations of preschool education: The predictive role of preschool quality for the development of mathematical skills through elementary school. Early Childhood Research Quarterly, $36,475-488$.

Lehrl, S., Kluczniok, K., Rossbach, H. G. ve Anders, Y. (2017). Longer-term effects of a high-quality preschool intervention on childrens mathematical development through age 12: Results from the German model project Kindergarten of the Future in Bavaria. Global Education Review, 4(3).

Li, K., Zhang, P., Hu, B. Y., Burchinal, M. R., Fan, X. ve Qin, J. (2019). Testing the 'thresholds' of preschool education quality on child outcomes in China. Early Childhood Research Quarterly, 47, 445-456.

Masrai, A. (2018). The 1mpact of preschool education on 11 vocabulary development and sequential bilingualism: the case of arab schoolchildren. International Journal of Applied Linguistics and English Literature 7(4), 121-128.

Morgan, H. (2019). Does High-Quality Preschool Benefit Children? What the Research Shows. Education Science, 9(1), 1-9.

OECD (2017). Starting Strong 2017: Key OECD Indicators on Early Childhood Education and Care. Organization for Economic Co-operation and Development: Paris, France, 2017. https://read.oecd-ilibrary.org/education/starting-strong-2017_9789264276116-en\#page5.

Oktay, A. (2007). Yaşamın sihirli yılları: okul öncesi dönem. İstanbul: Epsilon.

Özbey, S., ve Köyceğiz, M. (2019). Investigation of the effect of social skills training on the motivation levels of preschool children. International Electronic Journal of Elementary Education, 11(5), 477-486.

Patsopoulous N, Evangelou E. ve Ioannidis JPA. (2008). Sensitivity of between-study heterogeneity in meta-analysis: proposed metrics and empirical evaluation. Int J Epidemiol, 37(5), 1148-1157.

Polat Unutkan, Ö. (2007). Okul öncesi dönem çocuklarının matematik becerileri açısından ilköğretime hazır bulunuşluğunun incelenmesi. Hacettepe Üniversitesi Ĕ̆itim Fakültesi Dergisi, 32, 243 254.

Rodriguez, A. M. (2019). Parents' perceptions of early childhood music participation. International Journal of Community Music, 12(1), 95-110.

Singh, R. ve Mukherjee, P. (2018). Effect of preschool education on cognitive achievement and subjective wellbeing at age 12: evidence from India. Compare: A Journal of Comparative and International Education.

Taner, M ve Başal, H. A. (2005). Farklı sosyoekonomik düzeylerde okulöncesi eğitimi alan ve almayan ilköğretim birinci sınıf öğrencilerinin dil gelişimlerinin cinsiyete göre karşılaştırılması. Uludağ Üniversitesi Eğitim Fakültesi Dergisi, 18(2), 395-420.

Tatlıpınar, S., ve Serçe, H. (2019). Satranç öğretiminin okul öncesi çocukların dikkat toplama becerilerine etkisi. Selçuk Üniversitesi Sosyal Bilimler Meslek Yüksekokulu Dergisi, 22(2), 481-489.

Tavşancıl, E. ve Aslan, E. (2001). Sözel, yazılı ve diğer materyaller için içerik analizi ve uygulama örnekleri. İstanbul: Epsilon.

Üstündă̆, K., ve Ergin, B. (2020). Montessori yönteminin okul öncesi dönemdeki çocukların bilimsel süreç becerilerine etkisinin incelenmesi. Electronic Turkish Studies, 15(2), 1483-1498.

Vazou, S., Pesce, C., Lakes, K. ve Smiley-Oyen, A., (2019). More than one road leads to Rome: A narrative review and meta-analysis of physical activity intervention effects on cognition in youth, International Journal of Sport and Exercise Psychology, 17(2), 153-178. 
Vardi, Ö. ve Demiriz, S. (2019). Okul öncesi öğretmenlerinin çocukların meraklarına yönelik görüşleri. e-Kafkas Ĕ̌itim Araştırmaları Dergisi, 6(4), 44-56.

Wick, K., Leeger-Aschmann, C. S., Monn, N. D., Radtke, T., Ott, L. V., Rebholz, C. E., Cruz, S., Gerber, N., Schmutz, E. A., Puder, J. J., Munsch, S., Kakebeeke, T. H., Jenni, O. G., Granacher, U. ve Kriemler, S. (2017). İnterventions to promote fundamental movement skills in childcare and kindergarten: A systematic review and meta-analysis. Sports Medicine, 47, 2045-2068.

Yeşilyaprak, B. (2006). Gelişim ve Öğrenme Psikolojisi. Ankara: Pegem Yayıncılık.

Yılmaz Bolat, E. (2019). Okul öncesi öğretmenlerinin okuma yazmaya hazırlık çalışmaları konusundaki görüşleri. Turkish Journal of Social Research/Türkiye Sosyal Araştırmalar Dergisi, 23(1), 271-286.

YÖK, (2020). Yükseköğretim Kurulu Başkanlığı Tez Merkezi İstatistikleri. https://tez.yok.gov.tr/UlusalTezMerkezi/istatistikler.jsp sitesinden alınmıştır.

Zhang, S. (2017). Effects of attending preschool on adolescents' outcomes: evidence from China.Applied Economics, 49(27), 2618-2629. 


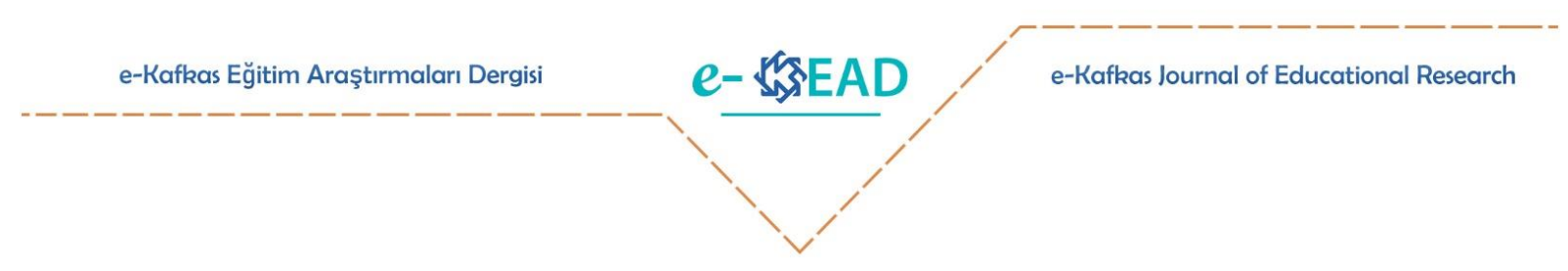

\title{
Investigation of Educational Practices Supporting the Psychomotor Development of Preschool Children in Turkey: A Meta-Analysis Study.
}

\author{
Osman Basit Ümit Deniz
}

To cite this article: Basit, O. ve Deniz. Ü. (2020). Investigation of educational practices supporting the psychomotor development of preschool children in Turkey: A meta-analysis study. e- Kafkas Ĕgitim Araştırmaları Dergisi, 7, 100-118. doi: 10.30900/kafkasegt.743149

Research article

Received:27.05.2020
Accepted: 10.07 .2020

\section{Introduction}

Preschool years are a period that forms the basis of all areas of the development of human life. The type and quality of the experiences provided to the child in this period largely depend on the variety of the opportunities that the adult can give him (Oktay, 2007). Many of the developed countries have increased their pre-school education rate to over $90 \%$, as it is accepted that the quality education offered to children from early ages contributes to the development level of children and the maturity of starting basic training. There are many educational models, approaches, and program suggestions on how to support children in which areas of development. These suggestions can be a training program that includes sustaining a single development area or a model that contributes to whole development of children.

In this research, education programs applied to support the psychomotor development areas of children are discussed. Psychomotor development, which develops in parallel with physical development, means that the individual (child's) limbs such as arms and legs become coordinated with all of the organs, the movements are taken under control and can be done skilfully (Yeşilyaprak, 2006). Psychomotor development; It includes changes that occur due to growth and maturation in the human body. Alterations in motor skills, brain, and motor coordination, and some hormonal changes are examined in the field of psychomotor development. Psychomotor development is closely related to the growth in the neuro-muscular systems. Competitive movements, mainly controlled during infancy, are considered as indicators of the development of babies. Many studies are carried out on how to support children's psychomotor development.

Scientific studies carried out by academics or postgraduate students play a crucial role in the development of society. Experimental studies in the field of education, as well as in many areas of science are essential in terms of increasing the quality of education. As a result of scientific studies, scientists all over the world publish thousands of articles, theses, papers, and books every day. As the number of scientific studies increases, the need for comprehensive and systematic research synthesis increases. One of the most effective methods for synthesizing individual studies is meta-analysis. Meta-analysis means combining the numerical results of researches whose ways and results are different, even contradicting each other. Meta-analysis allows researchers to achieve more clear results than any of the studies they included in the analysis (Hunt, 1997). Borenstein, Hedges, Higgins, and Rothstein (2013) defined "Meta-analysis as statistical synthesis of results in the study series."

When pre-school literature is examined, individual studies involving educational interventions supporting children's developmental areas are encountered. However, there is no meta-analysis study aiming at revealing the impact of these intervention programs on children's development. It is thought that a meta-analysis study conducted to show what extent experimental interventions with different study groups affect the development of children is important in terms of seeing the general picture. For 
this reason, postgraduate theses published between 1998-2020, which are stated to support psychomotor development, were examined in terms of their purpose, method, and results. Within the scope of the research, it is aimed to reveal the effects of interventions applied to pre-school children on the development of pre-school children in the psychomotor field in postgraduate theses. For this purpose, answers to the following questions were sought:

1. What are the education programs applied to pre-school children?

2. What is the effect of education programs implemented to pre-school children on children's psychomotor development?

\section{Method}

The model of this research is a meta-analysis, one of the systematic methods of synthesis. Meta-analysis is the synthesis and interpretation of the findings obtained from independent individual studies using various statistical techniques. The purpose of the meta-analysis is to reach the most quantitatively correct one by combining the results and increasing the sample size obtained from studies on the same subject at different places and time to reveal the facts (Cumming, 2012).

The research sample consists of 28 postgraduate theses published in Turkey, between 19982020 (the scan was terminated on 15/03/2020), including educational interventions to support the development of children's psychomotor domain of preschoolers. Of these theses designed in experimental design, 19 are master's, and 9 are doctoral theses.

The criteria used in the selection of the studies included in the research are presented below.

Criterion 1: Being done between 1998-2020.

Criterion 2: Experimentally conducted master and doctoral theses containing educational interventions implemented to support the psychomotor development of pre-school children with healthy growth in Turkey.

Criterion 3: Descriptive statistical data of the studies included in the study are needed to calculate the effect sizes required for the meta-analysis study. Therefore, studies, including sample size, arithmetic mean, and standard deviation values were included in the study.

The first screening for the research was carried out in June 2019 and the second in March 2020, using various keywords through the national thesis center. Comprehensive Meta-Analysis V3.0 (CMA) software trial copy was used to analyze the data obtained from the studies included in the research. Appropriate statistical analysis was performed in the light of data such as arithmetic mean, standard deviation, and sample sizes. Since the significance level of the studies included in the scope of the survey was taken as 0.05 , the significance level of the statistical analysis was determined as 0.05 in this study.

\section{Findings}

Publication bias of the studies included in the study was evaluated using the funnel scatter plot, and no publication bias was found. Cochrane's Q statistics and $\mathrm{I}^{2}$ index were used to determine the heterogeneity between studies. It has been interpreted that when $\mathrm{I}^{2}$ statistics is below $25 \%$, it is low when it is between $25-50 \%$, and when it is above $50 \%$, it is high heterogeneity (Patsopoulos, Evangelo, and Ioannidis, 2008).

In the heterogeneity evaluation of the model, $\mathrm{I}^{2}$ value was found as 83.83 , and it was determined that there was heterogeneity between the studies. In addition, the model was observed to be heterogeneous according to the $\mathrm{Q}$ test $(\mathrm{Q}: 166.98, \mathrm{p}<0.001)$. According to the random-effects model, the data in 28 studies included in the meta-analysis were calculated to be significant in favor of the experimental group in which educational intervention was performed with an effect size value of $\mathrm{ES}=0.671$, with the upper limit of 0.914 and the lower limit of 0.402 .

\section{Discussion, Conclusion, and Recommendations}

In Turkey, between the years 1998-2020, the number of interventions in support of the thesis for psychomotor development is less than the number of thesis for other development areas. However, 
there has been an increase in the number of thesis studies involving intervention in the psychomotor field in the last decade. When examining these studies, many descriptive, relational, or experimental studies are applied infusion classes or with children with special needs, as well as studies conducted with parents, teachers, prospective teachers and administrators prepared according to qualitative and quantitative paradigms. Studies conducted with different methods and groups are excluded from this research. In this study, the effect of educational intervention programs applied to pre-school children on the development of children in psychomotor fields is emphasized.

The number of samples belonging to 28 studies included in the study is 1575,792 of which are experiment and 783 of which are control. It is seen that most of the theses examined within the scope of the research are master's theses applied in independent public kindergartens in Ankara and Istanbul city centers. To support the development of children in the psychomotor field, the thesis was published mostly at Marmara University in 2010.

The publication bias of the studies included in the study was done using the funnel scatter plot, and it was determined that there was no publication bias. While the effect sizes of 28 studies that compose a sample of 1575 people were calculated, 17 studies did not find statistical significance, while 11 studies found a significant difference. As a result of the combining process in the randomeffects model, a positive and significant effect size of 0.671 was found in favor of the experimental group. According to Cohen (1998), the common effect size value calculated as a result of metaanalysis is a medium but close to a high level.

In literature, there was no meta-analysis study examining the psychomotor development of pre-school children in our country. However, there are relevant studies done on this subject abroad. It can be said that there is a similarity between the previous studies in the literature and the results of this research. (Burns, Fu \& Podlog, 2017; Capelle, Broderic, van Doorn \& Ward, 2017; Engel, Broderic, van Doorn, Hardly \& Parmenter, 2018; Johnstone, 2018; Wick et al. 2017). In addition to these studies, besides the effects of physical intervention programs on psychomotor development, metaanalysis studies examining the impact of cognitive development and academic success were also found (Alvarez-Bueno et al. 2017; Alvarez-Bueno et al. 2020; de Greeffa, Boskerb, Oosterlaand, Visschera \& Hartman 2018; Vazou, Pesce, Lakes \& Smiley-Oyen, 2019).

Based on the findings of the research, it is recommended that studies related to other development areas of pre-school children can be carried out. Another suggestion is to encourage researchers to make their theses accessible by the National Thesis Center. Also, more systematic and available databases that bring together studies (thesis, articles, and papers) made in any field of science should be created to expand the studies carried out by the meta-analysis method in our country. 


\section{EK. 1}

\section{Araştırmaya Dahil Edilen Tezlerin Kaynakçası}

1. Akgün, S. (2019). Hareket eğitimi ve imgelemenin okulöncesi eğitim kurumlarındaki 4-6 yaş grubu çocuklarda motor gelişime etkisi (Yayınlanmamış Yüksek Lisans Tezi). Trabzon: Trabzon Üniversitesi.

2. Akınbay, H. (2014). Okul öncesi dönemde oyunun önemi ve çocukların motor gelişimi üzerine etkileri (Yayınlanmamış Yüksek Lisans Tezi). Konya: Selçuk Üniversitesi.

3. Altınkök, M. (2006). Temel motor hareketlerin geliştirilmesini içeren beden eğitimi program tasarısının 5-6 yaş çocukların temel motor hareketlerinin gelişimine etkisinin araştıılması (Yayınlanmamış Yüksek Lisans Tezi). İstanbul: Marmara Üniversitesi.

4. Beken, S. (2009). Montessori yöntemi etkinliklerinin 5-6 yaş çocuklarının el becerilerinin gelişimine etkisi (Yayınlanmamış Yüksek Lisans Tezi). Aydın: Adnan Menderes Üniversitesi.

5. Beyazit, H. (2012). Hareketli müzik etkinliklerinin anasınıfi çocuklarında beden koordinasyonu gelişimine etkisi (Yayınlanmamış Yüksek Lisans Tezi). İstanbul: Marmara Üniversitesi.

6. Boz, M. (2011). 5-6 yaş grubu çocuklara uygulanan Temel Hareket Eğitim Programının hareket becerilerinin gelişimine etkisi (Yayınlanmamış Doktora Tezi). Ankara: Gazi Üniversitesi.

7. Çelik Arslan, A. (2012). Dans eğitim programinın anaokuluna devam eden 6 yaş grubu çocukların motor performans düzeyine etkisi (Yayınlanmamış Yüksek Lisans Tezi). Ankara: Hacettepe Üniversitesi.

8. Demir, A. (2018). Okul öncesi çocuklarda aktif video oyunları ve denge antrenmanı etkilerinin incelenmesi (Yayınlanmamış Doktora Tezi). Mersin: Mersin Üniversitesi.

9. Ercan, Z. G. (2009). Anasınıfina devam eden altı yaş çocuklarına verilen görsel algı eğitiminin görsel-motor koordinasyon gelişimine etkisinin incelenmesi (Yayınlanmamış Doktora Tezi). Ankara: Ankara Üniversitesi.

10. Erdemir, S. (2010). Erken destek eğitim programının 18-36 aylık çocukların gelişimine etkisinin incelenmesi (Yayınlanmamış Yüksek Lisans Tezi). İstanbul: Marmara Üniversitesi.

11. Ergişi, A. (2014). Türkçe etkinliklerinin anasınıfina devam eden çocukların gelişimlerine etkisinin incelenmesi (Yayınlanmamış Doktora Tezi). Ankara: Ankara Üniversitesi.

12. Gül, M. (2006). Anasinıfina devam eden alt sosyo ekonomik düzeydeki 61-72 ay arası çocuklara sembolik oyun eğitiminin etkisinin incelenmesi (Yayınlanmamış Yüksek Lisans Tezi). Gazi Üniversitesi Eğitim Bilimleri Enstitüsü, Ankara.

13. Karaman, B. (2019). Okul öncesi ĕgitim kurumlarında oynatılan fiziksel etkinliğe dayalı oyunların psikomotor gelişimi üzerine etkisi (Yayınlanmamış Yüksek Lisans Tezi). Aksaray: Aksaray Üniversitesi.

14. K1lıç, Z. (2018). CHAMPS motor beceriler protokolü'nün (CMBP) Türkçeye uyarlanması ve CATCH programı hareket etkinliklerinin çocukların lokomotor ve nesne kontrolü becerileri üzerindeki etkisinin incelenmesi (Yayınlanmamış Doktora Tezi). İstanbul: Marmara Üniversitesi.

15. Kırıcı, H. M. (2008). Okulöncesi eğitim kurumlarındaki 4-6 yaş grubu çocuklarda 8 haftalık hareket eğitiminin motor performanslarına etkisi (Yayınlanmamış Yüksek Lisans Tezi). Muğla: Muğla Üniversitesi.

16. Mülazımoğlu Ballı, Ö. (2006). Bruininks-Oseretsky motor yeterlik testinin geçerlik, güvenirlik çalışması ve beş-altı yaş grubu çocuklara uygulanan cimnastik eğitim programının motor gelişime etkisinin incelenmesi (Yayınlanmamış Doktora Tezi). Ankara: Ankara Üniversitesi. 
17. Özbek, Ö. Y. (2011). 60-72 ayllk çocuklara uygulanan aile katılıml ilkögretime hazırlık programının çocukların ilköğretime hazır bulunuşluluk düzeyine etkisi (Yayınlanmamış Yüksek Lisans Tezi). İstanbul: Marmara Üniversitesi.

18. Özdenk, Ç. (2007). 6 yaş grubu öğrencilerinin psikomotor gelişimlerinin sağlanmasında oyunun yeri ve önemi (Yayınlanmamış Yüksek Lisans Tezi). Elazığ: Fırat Üniversitesi.

19. Öztürk, A. (2009). 5-6 yaş grubu çocuklarda farklı hareket eğitim modellerinin fiziksel gelişim ve fiziksel uygunluk özelliklerine etkisinin incelenmesi (Yayınlanmamış Yüksek Lisans Tezi). İstanbul: Marmara Üniversitesi.

20. Sarıtaş, R. (2010). Milli Eğitim Bakanlı̆̆ okul öncesi eğitim programına uyarlanmış GEMS (great explorations in math and science) fen ve matematik programinin anaokuluna devam eden altı yaş grubu çocukların kavram edinimleri ve okula hazır bulunuşluk düzeyleri üzerindeki etkisinin incelenmesi ( Yayınlanmamış Yüksek Lisans Tezi). Ankara: Gazi Üniversitesi.

21. Suveren Erdoğan, C. (2014). Okul öncesi eğitim alan çocuklarda denge ve koordinasyon çalışmalarının bazı motorik özellikler üzerine etkisi (Yayınlanmamış Doktora Tezi). Ankara: Gazi Üniversitesi.

22. Şen, M. (2004). Anaokuluna devam eden altı yaş çocukların motor gelişimlerine beden eğitimi çalışmalarının etkisinin incelenmesi (Yayınlanmamış Yüksek Lisans Tezi). Ankara: Ankara Üniversitesi.

23. Taştepe, T. (2018). 36-47 aylık çocuklara ve annelere uygulanan motor gelişim destek programının çocukların motor gelişimine etkisinin incelenmesi (Yayınlanmamış Doktora Tezi). Ankara: Ankara Üniversitesi.

24. Toran, M. (2011). Montessori yönteminin çocukların kavram edinimi, sosyal uyumlar ve küçük kas motor becerileri üzerindeki etkisinin incelenmesi (Yayınlanmamış Doktora Tezi). Ankara: Gazi Üniversitesi.

25. Tuzcuoğlu, B. (2007). 6 yaş anasınıfi çocuklarına uygulanan egzersiz çalışmalarının koordinasyon gelişimine etkisi (Yayınlanmamış Yüksek Lisans Tezi). Sakarya: Sakarya Üniversitesi.

26. Tüfekçioğlu, E. (2002). Okul öncesi 4-6 yaş çocuklarında algısal motor gelişim programlarının denge ve çabukluk üzerine etkisi (Yayınlanmamış Yüksek Lisans Tezi). İstanbul: Marmara Üniversitesi.

27. Türel, E. (2019). Açık havada gerçekleştirilen oyun etkinliklerinin 24-36 aylık çocukların gelişsimlerine etkisinin incelenmesi (Yayınlanmamış Yüksek Lisans Tezi). Ankara: Ankara Üniversitesi.

28. Yavuz, N. F. (2016). Okul öncesi dönemde beden eğitimi ve spor etkinliklerinin çocukların hareket becerileri üzerine etkisinin incelenmesi (Yayınlanmamış Yüksek Lisans Tezi). Karabük: Karabük Üniversitesi. 